\title{
A case of regional metamorphism of Buchan type (andalusite-cordierite) in the Nortern Santander Massif, Eastern Cordillera (Colombia)
}

\author{
Oscar M. Castellanos ${ }^{1}$, Carlos A. Ríos ${ }^{2, *}$ \\ ${ }^{1}$ Grupo de Investigación en Geofísica y Geología (PANGEA), Programa de Geología, Universidad de Pamplona, Colombia \\ ${ }^{2}$ Grupo de Investigación en Geología Básica y Aplicada (GIGBA), Escuela de Geología, Universidad Industrial de Santander, Colombia
}

\begin{abstract}
The Lower Paleozoic Silgará Formation in the northern Santander Massif was affected by Caledonian prograde regional metamorphism, which varies from low to medium grade and is represented by greenschist, epidoteamphibolite and amphibolite facies. The Silgará Formation shows evidence of a regional metamorphism of Buchan type (andalusite-cordierite) attributed to a crust that was affected by a considerable addition of heat due to magmas which was overimposed on the Barrovian metamorphism that characterize this massif. An anticlockwise PT path reveals that the initial conditions are represented by the mineral assemblage of chloritoid+pryrophyllite+chlorite (all assemblages with quartz+muscovite) in greenschist facies and the final conditions correspond to the mineral assemblage of sillimanite+biotite+cordierite (+muscovite+quartz+garnet if sufficient $\mathrm{MnO}$ and $\mathrm{CaO}$ are present) in amphibolite facies due to the reaction andalusite $=$ sillimanite occurred at $600{ }^{\circ} \mathrm{C}$ and $2.4 \mathrm{kbar}$. Additionally, in these rocks several deformation events and evidences of shearing and intracrystalline deformation were found.
\end{abstract}

Key words: Silgará Formation, Santander Massif, mineral assemblages, metamorphism, P-T path.

Un caso de metamorfismo regional tipo Buchan (andalucita-cordierita) en la región Norte del Macizo de Santander, Cordillera Oriental (Colombia)

\section{Resumen}

La Formación Silgará del Paleozoico Inferior en la parte norte del Macizo de Santander fue afectada por un metamorfismo regional progrado Caledoniano, el cual varía de bajo a medio grado y está representado por las facies esquistos verdes, epidota-anfibolita y anfibolita. La Formación Silgará muestra evidencia de un metamorfismo regional de tipo Buchan (andalucita-cordierita) atribuido a una corteza que ha sido afectada por una adición considerable de calor debido a magmas, el cual fue sobreimpuesto al metamorfismo Barroviense que caacteriza a este macizo. Una trayectoria de PT antihoraria revela que las condiciones iniciales están representadas por la asociación mineral de cloritoide+pirofilita+clorita (todos las paragénesis con cuarzo+moscovita) en la facies de esquistos verdes y las condiciones finales corresponden a la asociación mineral de silimanita + biotita + cordierita (+moscovita+cuarzo+granate si suficiente $\mathrm{MnO}$ y CaO están presentes) en la facies anfibolita debido a la reacción andalucita $=$ silimanita que ocurrió a $600{ }^{\circ} \mathrm{C}$ y 2.4 kbar. Adicianalmente, en estas rocas se encontraron varios eventos de deformación y evidencias de cizallamiento y deformación intracristalina

Palabras clave: formación Silgará, Macizo de Santander, paragénesis minera, metamorfismo, trayectoria P-T.

\section{Introduction}

The Santander Massif is situated in the Eastern Cordillera (Colombian Andes), where it is divided into the NESWtrending Perijá range in Colombia and the ENE-WSWtrending Mérida Andes in Venezuela (Figure 1). During the last decades, the Santander Massif's metamorphic rocks have been focus of interest in several studies (e.g., RestrepoPace, 1995; Restrepo-Pace et al., 1997; Schäfer et al. 1998; Ríos, 1999, 2001, 2005; Castellanos, 2001; Mantilla et al., 2001, 2002, 2003; Ríos et al. 2003a, 2003b, 2008a, 2008b;
Cardona, 2003; Castellanos et al., 2004, 2008, 2010; García et al., 2005), which mostly were directed towards the estimation of metamorphic conditions, considering the importance of this ancient massif as key to understanding the complex geotectonic evolution of the northwestern continental margin of South America. The pre-Devonian

\footnotetext{
*Corresponding author:

Carlos A. Ríos, carios@uis.edu.co

Recibido: 20 de enero de 2015

Aceptado: 2 de junio de 2014
} 

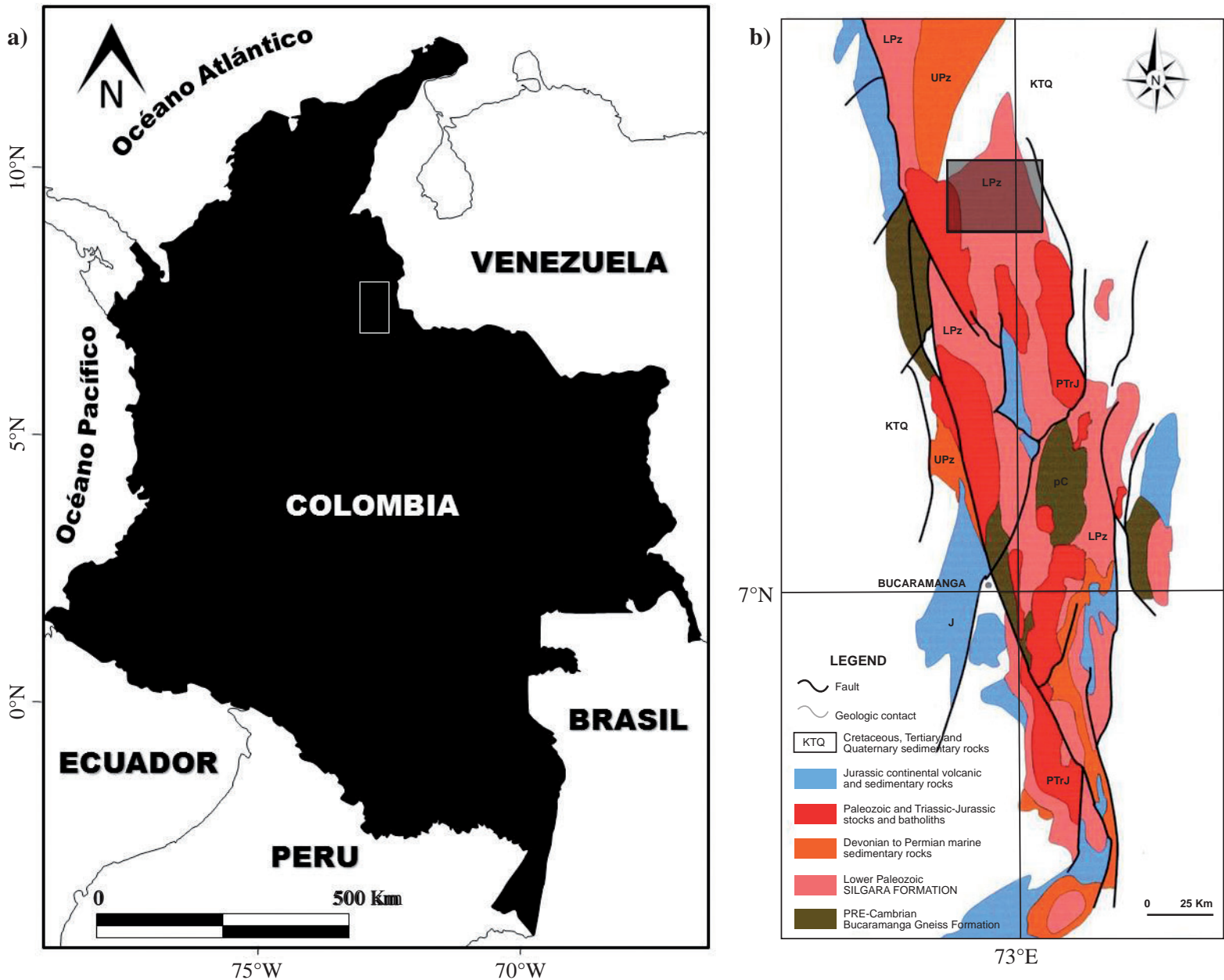

Figure 1. (a) General sketch of the location of the Santander Massif. (b) Generalized geological map of the Santander Massif (adapted and modified after Goldsmith et al., 1971).

metamorphic complex of the Santander Massif have been divided into the following geological units, in ascending order of tectono-stratigraphic level: Bucaramanga Gneiss Complex, Silgará Schists Formation, Chicamocha Schists Formation, Orthogneiss and San Pedro Phyllites Formation (e.g., Ward et al.,1973; Mantilla et al., 2015), all of which are cut by intrusive rocks that recorded magmatic events of Caledonian to Jurassic age (Goldsmith et al., 1971; Banks et al., 1985; Boinet et al., 1985; Dörr et al., 1995; RestrepoPace, 1995; Ordoñez, 2003; Ordóñez and Mantilla, 2005). Mantilla et al. (2015) reported the following U-Pb ages from detrital zircons: a Neo-Proterozoic age ( 900 Ma) for the Silgará Schists Formation, and a Middle Cambric age ( 500 Ma) for the Chicamocha Schists Formation. According to Mantilla et al. (2015), the climax of the metamorphism that affected these metamorphic units ocurred during the main event of the Fammatinian orogeny (Early Ordovician; 480$470 \mathrm{Ma}$ ), which can be related to the emplacement of syntectonic granitoids of ages between 480 and 472 Ma that form part of the Orthogneiss (e.g., Mantilla et al., 2012). On the other hand, the San Pedro Phyllites Formation represents the youngest metamorphic unit in the Santander Massif, with a Late Ordovician age $(>450 \mathrm{Ma})$, although the metamorphism that affected it has not been determined by geochronologic methods (Mantilla et al., 2015). This metamorphic event, which has produced very low grade metamorphic rocks (e.g., phyllites and metasedimentary rocks, such as those observed in the suty area), can be related with a minor event of the Fammatinian orogeny (Mantilla et al., 2015). The basement of the Santander Massif is unconformably overlain by sedimentary sequences of Devonian to Tertiary age (Ward et al., 1973). Ríos and coworkers (Ríos, 1999, 2001, 2005; Ríos and Takasu, 1999; Campos, 1999; Montenegro y Barragán, 1999; García y Campos, 2000; Ríos and García, 2001; Castellanos, 2001; Mantilla et al., 2001, 2002, 2003; Gélvez and Márquez, 2002; Ríos et al. 2003a, 2003b, 2008a, 2008b; Cardona, 2003; Castellanos et al., 2004, 2008, 2010; García et al., 2005; Gómez y Avila, 2006) have conducted in the last decade numerous studies on the geological evolution of the different metamorphic units outcropping in the Santander Massif, emphasizing on the metamorphic rocks 
of the Silgará Formation, modifying the classic scheme of metamorphic zones and isograds proposed by Ward et al. (1969, 1970), revealing a complex history of metamorphism and deformation for this geologic unit. The purpose of this work is to reconstruct the tectono-metamorphic evolution of the metamorphic sequence of the Silgará Formation exposed in the Northern Santander Massif (NSM) as a contribution to knowledge and understanding of the development of orogenic processes in the Colombian Andes.

\section{Geological context}

The rocks of interest in this study correspond to the metapelitic sequence Silgará Formation exposed in the NSM, which generally trend NW and dip in a moderate to steep angles toward NE or NW. The main regional structure is represented by the NW-trending, nearly vertical Bucaramanga - Santa Marta Fault in the southwest of the study area, which is probably strike-slip with protracted deformation (Goldsmith et al., 1971), strongly influencing the tectonic in the study area as revealed by a very complex tectonic history. This fault is the responsible of a NW fault system, within which are the San Calixto, Las Mercedes, El Tarra and Hacarí, the first two of them representing the tectonic limits (thrusting faults) of the metapelitic sequence described above. The San Calixto Fault promotes the thrusting of Precambrian rocks on the igneous-metamorphic complex, whereas the Las Mercedes Fault promotes the thrusting of promotes the igneous-metamorphic complex on Cretaceous and Tertiary rocks. The metapelitic sequence of the Silgará Formation is divided in three long stripes; Western (Hacarí - La Playa - Guayabal - Abrego - Tarra sector), Central (Tarra - La Curva sector), and Eastern (La Fortuna - Sardinata sector), as shown in Figure 2. It was affected by the quartzmonzonite Aguablanca Batholith and the Intrusive - Extrusive Igneous Complex (quartzmonzonite intrusive phase and ryolite effusive explossive volcanism series) of approximate NS direction. Here, the Silgará Formation is composed mainly of pelitic rocks with thin interlayers of psammitic, semipelitic, metabasic and metacarbonate rocks, which were affected by a regional metamorphism during the Caledonian orogeny, recognizing a different type of metamorphism as revealed by a progressive mineral sequence that defined a pattern of metamorphic zonation (biotite $\rightarrow$ andalusite $\rightarrow$ cordierite $\rightarrow$ silimanite) after a metamorphism of Buchan type under low-P and high-T conditions. Pelitic rocks were affected by

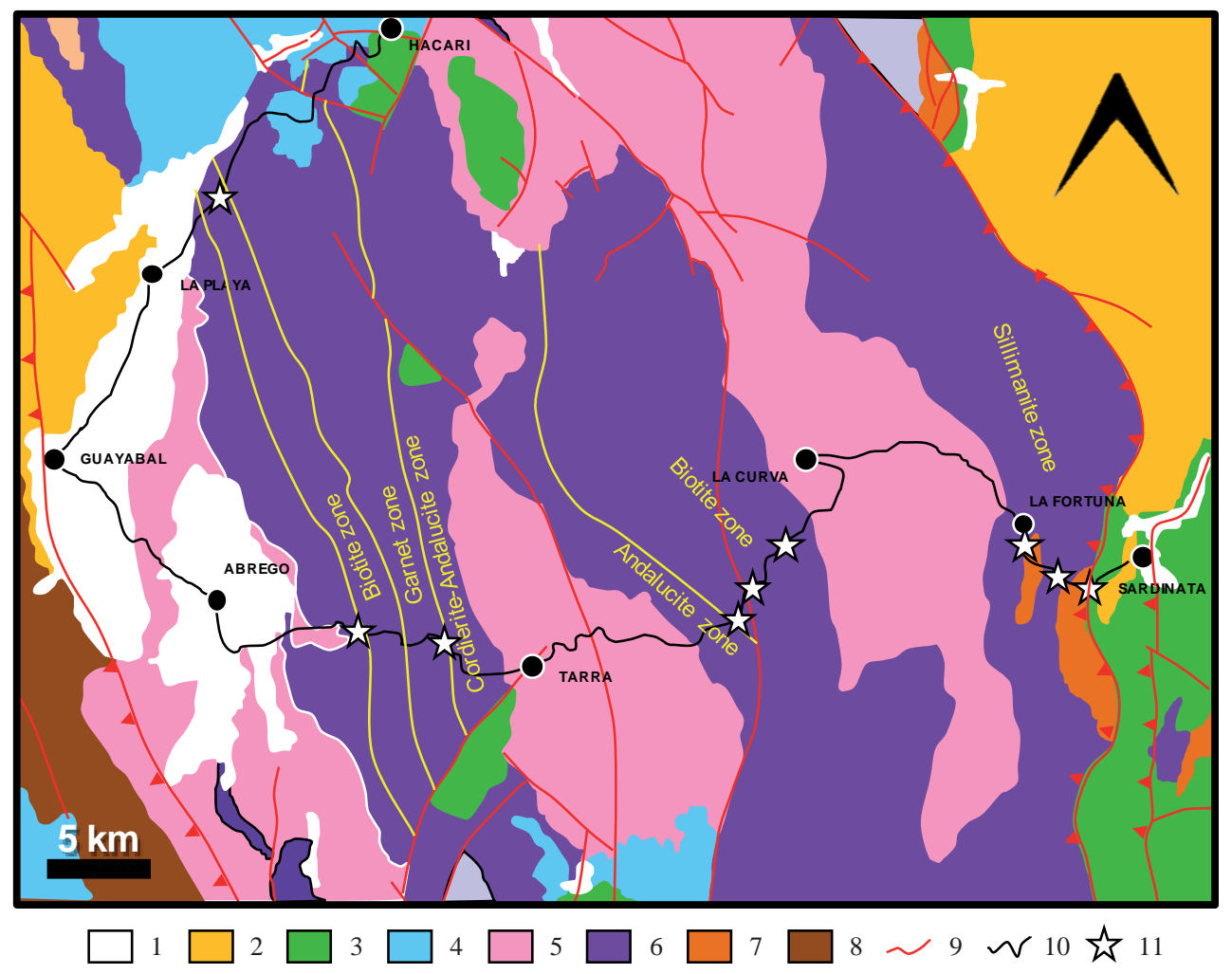

Figure 2. Generalized geological map of the study area, showing the three stripes in which the metapelitic sequence of the Silgará Formation is divided (modified after Clavijo, 1977). 1 (Quaternary sedimentary deposits); 2 (Tertiary continental sedimentary rocks); 3 (Cretaceous epicontinental sedimentary rocks); 4 (Jurassic continental sedimentary rocks); 5 (Jurassic acid and intermediate plutonic and volcanic rocks); 6 (Pre-Devonian metamorphic rocks of sedimentary protolith - Silgará Formation); 7 (Cambrian metamorphic rocks of ígneous protolith - Orthogneiss); 8 (Precambrian metamorphic rocks of sedimentary protolith - Bucaramanga Gneiss Complex); 9 (Fault); 10 (Road); 11 (Sampling locality). 
multiple deformations, giving rise to interference patterns. This metamorphism can be atributed to the igneous activity operating as metamorphism proceeds.

Figure 1S, http://www.raccefyn.co/index.php/raccefyn/ article/downloadSuppFile/108/692. illustrates several features about the field occurrence of metapelitic rocks of Silgará Formation in the NSM, particularly, in the western, central and eastern stripes, which are describes as follows:

Western stripe (Figures 1Sa-1Sb). In this sector the metamorphic sequence is represented mainly by phyllites, quartzites, metasandstones and schists, the former being the predominant lithotype. These rocksshow a tabular geometry (10-60 cm thick) and poorly developed schistose structure, slightly subparallel foliation, intense jointing, and yellowish brown to gray depending on the degree of alteration. In some cases, biotite aggregates giving a mottled appearance to the rock. Quartz veins (aproximately $0.1 \mathrm{~cm}$ thick) are locally observed. Phyllites show a foliation with direction $\mathrm{N} 5^{\circ} \mathrm{E}$ and dip $60^{\circ} \mathrm{SE}$ or $60^{\circ} \mathrm{NW}$, although almost vertical foliations were also observed. Schists occur in two varieties; micaschists with or without cordierite and andalusite. The first of them occur as highly jointed massive bodies with schistose and mottled structure and subparallel foliation (direction 30$65^{\circ} \mathrm{NW}$, dipping $60^{\circ} \mathrm{NE}$ and $60^{\circ} \mathrm{SW}$, although almost vertical foliations were also observed); in some parts a compositional banding ( $0.4 \mathrm{~cm}$ thick) can be observed. The latter of them occur as highly jointed massive bodies with schistose structure and undulating subparallel foliation $\left(\mathrm{N} 10^{\circ} \mathrm{W} / 70^{\circ} \mathrm{NE}\right.$ or $\mathrm{N} 5^{\circ} \mathrm{E} / 45^{\circ} \mathrm{NW}$ ), but NS foliations and vertical dip were also observed). Quartz veins (0.5-1.5 cm thick) are locally observed. Other varieties of rocks are represented by quartzites, metasandstones and metaconglomerates cropping out along the Los Angeles and Paramillo streams, developing highly jointed tabular bodies with variable thickness (20$50 \mathrm{~cm}$ ), with thin interbedded phyllites. Quartzites show a massive structure and they are very compact and are cross cut by quartz veins $(0.1 \mathrm{~cm}$ thick). Metasandstones and metaconglomerates display a massive structure, although they locally develop a banded structure, with the last of them containing rounded boulders of about $0.5-1 \mathrm{~cm}$ in average diameter. Quartz veins (0.2 cm thick) were also observed. Micaschists and metawackes crop out towards the sector La Playa - Hacarí. Fine- to coarse-grained micaceous schists show a well-developed schistose and locally banded structure, parallel to undulating subparallel foliation. They are yellowreddish depending on the degree of alteration and show little compaction because they break easily following the foliation surface. Fine-grained metawackes show a reddish color and present quartz porphyroclasts. In this stripe the average foliation is approximately of direction $5-35^{\circ} \mathrm{NW}$ and dip $45-60^{\circ} \mathrm{NW}$ or $\mathrm{NS} / 60^{\circ} \mathrm{E}$.

Central stripe (Figures 1Sc-1Se). Highly jointed and weathered medium-grained andalusite-bearing schists crop out in this sector, displaying a banded and slightly schistose structure and parallel plane foliation (approximately $\mathrm{N} 50^{\circ} \mathrm{W} / 45^{\circ} \mathrm{NE}$ ). Additionally, graphite slates with and without andalusite cropping out as structurally very complex bodies due to their high degree of jointing. The average foliation of these rocks is $\mathrm{N} 60^{\circ} \mathrm{W} / 45^{\circ} \mathrm{NE}$. Very finegrained andalusite-bearing graphite slates of light to dark gray color and silky luster show a poor-developed schistose structure, lepidoblastic texture and slightly subparallel foliation. Andalusite-absent graphite slates show similar features to those observed in andalusite-bearing graphite slates, except by the absent of andalusite. They generally show a dark gray color and higher weathering with rusty surfaces. Fine-grained graphite phyllites of dark gray and orange in rusty bands and silky luster occurs along with graphite slates described above, cropping out as tabular bodies of different thickness characterized by compositional banding of rusty appearance (approximately of 0.7$1.2 \mathrm{~cm}$ thick), lepidoblastic texture and coarse foliation. The average foliation of these rocks is $\mathrm{N} 80^{\circ} \mathrm{W} / 60^{\circ} \mathrm{NE}$. Towards the center of this stripe, a sequence of interbedded slates and quartzites occurs. Quartzites crops out as thick tabular and very jointed bodies, which are characterized by a massive structure, compact appearance and granoblastic texture. They show light to dark gray and greenish gray color quartz veins of 0.1-0.2 cm thick. Sometimes, the quartzites show a compositional banding with very thin straight and parallel bands $(\leq 0.1 \mathrm{~cm})$ of dark green color. Highly jointed very fine-grained greenish gray slates crop out as tabular bodies of variable thickness (5-30 cm thick). They display a foliation of direction EW and vertical dipping or $\mathrm{N} 85^{\circ} \mathrm{W} / 60^{\circ} \mathrm{NE}$. These rocks show a greenish gray color and silky luster, lepidoblastic texture and coarse foliation. In some cases, a distinct compositional banding is observed with green bands in different tones and thickness. Toward the right edge of this stripe, a sequence of interbedded quartzites and phyllites crops out, predominating the first of them. Very jointed and fine- to medium-grained quartzites occur as tabular bodies with average thickness of 40-70 $\mathrm{cm}$. They are characterized by a massive structure, compact appearance, and lepidogranoblástica texture. Microveins of quartz (0.3 $\mathrm{cm}$ thick) and microfaults cross cut these rocks, which are mainly composed of quartz (some of this of coarse size), with muscovite and plagioclase. Fine-grained phyllites occur as tabular bodies of variable thickness, which are characterized by their poor-developed schistose structure, comptact appearance, subparallel foliation, and dark bluishgray color and silky luster.

Eastern stripe (Figurs 1Sf). A sequence of medium- to coarsegrained micaceous schists characterized by the presence of sillimanite occurs in this stripe. These rocks shows a gneissic to schistose structure, coarse to slightly subparallel foliation, lepidogranoblastic to granolepidoblastic texture, dark gray color, containing biotite, quartz, muscovite and plagioclase, among others. In parts quartz veins of $0.4 \mathrm{~cm}$ thickness are observed. 
Metapelitic rocks are the major constituents of the Silgará Formation, with minor intercalations of metamafic rocks. They display a well-developed schistosity, though sedimentary bedding is locally preserved and well displayed in low-grade metamorphic rocks of the biotite zone. The lithology of the sequence is characterizaed by the occurrence of the following lithotypes: phyllites, metasandstones, metawackes, micaschists, quartzites, andalusite-bearing slates and schists, garnet-bearing sillimanite schists, andalusite- and cordierite-bearing micaschists and metagabres. General macroscopic characteristics of the metapelitic rocks Silgará Formation observed at the NSM are shown in Figure 2S, http://www.raccefyn.co/index.php/ raccefyn/article/downloadSuppFile/108/692.

\section{Materials and methods}

Petrographic analyses of different metapelitic rocks were carried out to establish their textural and structural features as well as their mineralogy, using the transmitted light microscopy (Nikon triocular microscope, model Labophot2POL) of the School of Geology at the Universidad Industrial de Santander. On the other hand, this was very useful to deduce the reaction history of the metapelitic sequence, and its PT metamorphic conditions, constructing a PT path. The interpretations are based on the observed mineral assemblages in equilibrium in the lithotypes identified in this study, and the comparison between these mineral assemblages and results obtained by Ríos and co-workers (e.g., Ríos, 1999; Castellanos, 2001; Ríos et al. 2003a, 2008a; García et al., 2005; Castellanos et al., 2008) in other regions of the Santander Massif.

\section{Petrography}

A detailed petrographic study of thin sections was developed on all specimens. Figure 3 illustrates the main petrographic aspects of the Silgará Formation metapelitic rocks at the NSM. Mineral abbreviations are after Kretz (1983) and Bucher and Frey (1994). Mineral assemblages reveal that these rocks were affected by a regional metamorphism of Buchan type (andalusite-cordierite).

\section{Slates}

These rocks are composed mainly of biotite and ilmenite, and the typical mineral assemblage is quartz + biotite + muscovite. Plagioclase occurs as an accessory mineral. The protolith of the slates corresponds to very fine-grained pelitic sediments, which were affected by a metamorphism reaching the greenschist facies. They show lepidoblastic to granolepidoblastic textures, which are defined by the orientation of biotite and ilmenite. Figures 3a1 and 3a2 illustrate the main microstructural and textural features observed in this lithotype.

\section{Phyllites}

These rocks are characterized by the presence of muscovite and quartz, and the typical mineral assemblages are quartz + muscovite + biotite; quartz + muscovite + chlorite. Epidote, chloritoid, titanite and zircon occur as accessory minerals. Their protolith corresponds to fine-grained pelitic sediments, which were affected by a metamorphism reaching the greenschist facies. They show a lepidoblastic to granolepidoblastic textures, which are defined by the alignment of muscovite. Figures 3b1 and 3b2 illustrate the main microstructural and textural features observed in this lithotype.

\section{Slightly conglomeratic metasandstones}

These rocks are characterized by the following mineral assemblages: quartz + muscovite + biotite; quartz + biotite + plagioclase \pm K-feldspar; quartz + biotite + microcline. Apatite is the main accessory mineral. Their protolith corresponds to coarse-grained detritic quartz-rich sediments, which were affected by a metamorphism reaching the greenschist facies. They show a lepidogranoblastic texture, although a porphyroblastic texture with granolepidoblastic matrix can be locally recognized. Figures 3c1 and 3c2 illustrate the main microstructural and textural features observed in this lithotype.

\section{Metawackes}

These rocks are composed of quartz, muscovite, chlorite, and oxide minerals in a muddy matrix of brown color and earthy character. They show porphyroblasts of quartz, muscovite and oxide phases. Apatite is the main accessory mineral.

\section{Micaschists without garnet}

These rocks are composed mainly of biotite and muscovite, and the typical mineral assemblages are quartz + biotite + muscovite; quartz + plagioclase + muscovite; quartz + plagioclase + biotite. Epidote, zircon and tourmaline are the main accessory phases. Their protolith corresponds to medium- to coarse-grained pelitic sediments, which were affected by a metamorphism reaching the greenschist facies. They show a lepidogranoblastic to granolepidoblastic texture, which is defined by the alignment of mica minerals, developing a schistose structure. Figures 3d1 and $3 \mathrm{~d} 2$ illustrate the main microstructural and textural features observed in this lithotype.

\section{Micaschists with garnet}

These rocks are composed mainly of muscovite, with minor quartz, and the typical mineral assemblage is quartz + muscovite \pm garnet. Tourmaline occurs as the main accessory phase. Their protolith corresponds to mediumto coarse-grained pelitic sediments, which were affected by a metamorphism reaching the greenschist facies. They show a porphyroblastic texture with granolepidoblastic matrix, which is defined by the alignment of muscovite. Figures 3e1 and 3e2 illustrate the main microstructural and textural features observed in this lithotype. 


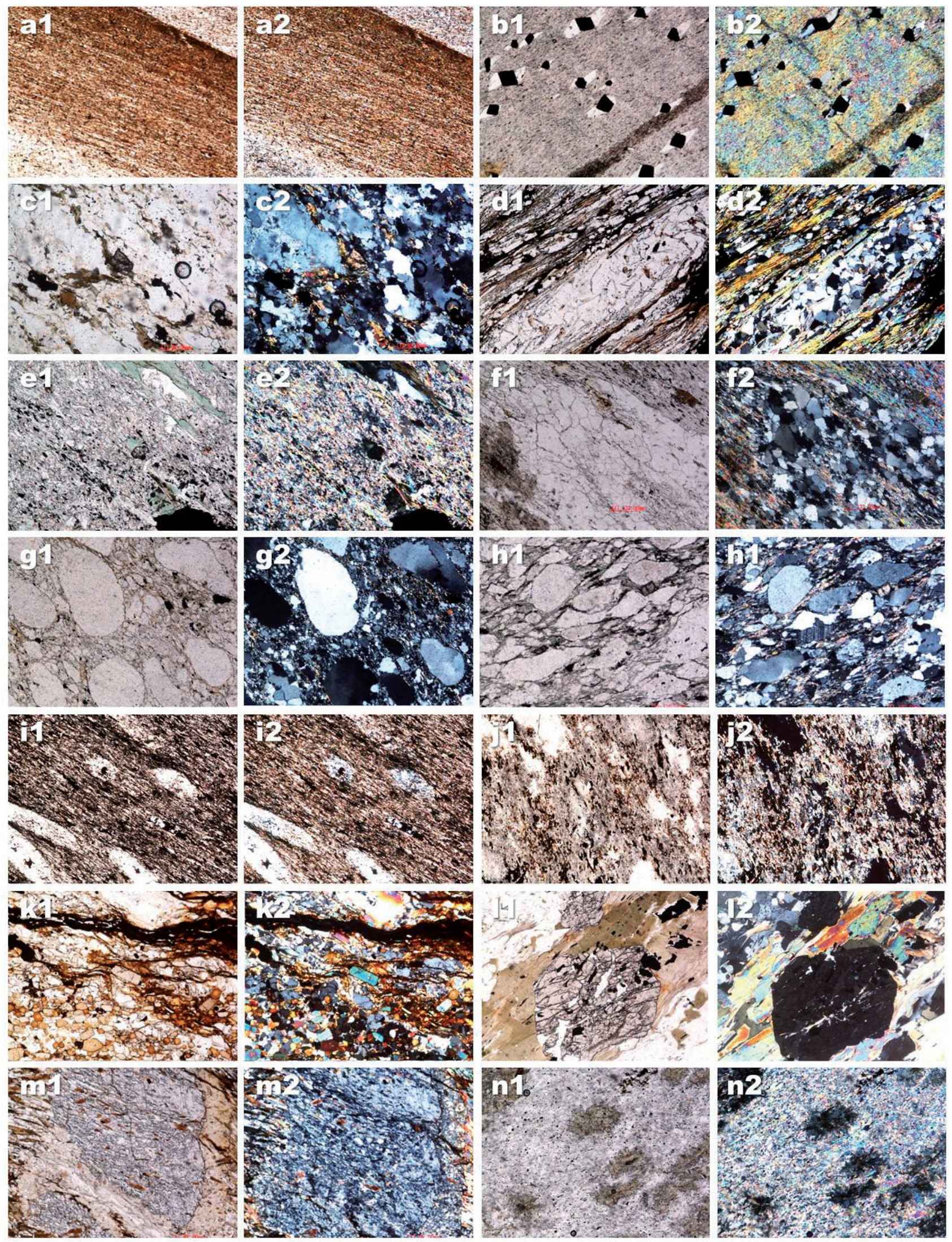

Figure 3. Photomicrographs in plane-polarized light and crossed-polarized light, respectively, of the different lithotypes identified in the metapelitic rocks of the Silgará Formation at the NSM. 


\section{Muscovite schists}

These rocks are composed mainly of muscovite, and the typical mineral assemblage is quartz + muscovite + biotite. Zircon and epidote occurs as the main accessory phases. Their protolith corresponds to medium- grained pelitic sediments, which were affected by a metamorphism reaching the greenschist facies. They show a granolepidoblastic to lepidogranoblastic texture, which is defined by the alignment of muscovite. Figures 3f1 and 3f2 illustrate the main microstructural and textural features observed in this lithotype.

\section{Quartzites}

These rocks are characterized by the following mineral assemblages: quartz + muscovite + biotite; quartz + plagioclase + muscovite. The accessory minerals are tourmaline, zircon and apatite. Their protolith corresponds to medium- to coarse-grained detritic quartz-rich sediments, which were affected by a metamorphism reaching the greenschist facies. They show a granoblastic texture Figures 3g1 and 3g2 illustrate the main microstructural and textural features observed in this lithotype.

\section{Micaceous quartzites}

These rocks are characterized by a high content of micaceous minerals, and the typical mineral assemblage is quartz + muscovite \pm plagioclase. The accessory minerals are tourmaline, zircon and apatite. Their protolith corresponds to medium- to coarse-grained detritic quartz-rich sediments, which were affected by a metamorphism reaching the greenschist facies. They show a lepidogranoblastic texture. Figures 3h1 and 3h2 illustrate the main microstructural and textural features observed in this lithotype.

\section{Andalusite-bearing graphite slates}

These rocks are characterized by the presence of andalusite porphyroblasts and high content of muscovite and graphite, and the typical mineral assemblage is quartz + muscovite \pm andalusite. Epidote occurs as an accessory mineral. Their protolith corresponds to fine- to mediumgrained pelitic sediments, which were affected by a metamorphism reaching the amphibolite facies. They show a porphyroblastic texture with lepidoblastic matrix, which is defined by the alignment of muscovite and graphite. Figures $3 \mathrm{i} 1$ and $3 \mathrm{i} 2$ illustrate the main microstructural and textural features observed in this lithotype.

\section{Andalusite-bearing muscovite schists}

These rocks are characterized by the presence of andalusite porphyroblasts in a matrix mainly composed of muscovite, and the typical mineral assemblage is quartz + muscovite \pm andalusite. Their protolith corresponds to mediumgrained pelitic sediments, which were affected by a metamorphism reaching the amphibolite facies. They show a porphyroblastic texture with lepidoblastic matrix, which is defined by the preferred orientation of muscovite. Figures $3 \mathrm{j} 1$ and $3 \mathrm{j} 2$ illustrate the main microstructural and textural features observed in this lithotype.

\section{Tourmaline- and andalusite-bearing schists}

These rocks are characterized by the presence of tourmaline and andalusite porphyroblasts, and the typical mineral assemblage is quartz + muscovite + andalusite. Their protolith corresponds to medium- to coarse-grained pelitic sediments, which were affected by a metamorphism reaching the amphibolite facies. They show a porphyroblastic texture with granoblastic, lepidogranoblastic and poiquiloblastic matrix. Figures 3k1 and 3k2 illustrates the main microstructural and textural features observed in this lithotype.

\section{Garnet-bearing sillimanite schists}

These rocks are characterized by the presence of garnet porphyroblasts and sillimanite, and the typical mineral assemblages are sillimanite + biotite + muscovite; biotite + muscovite + quartz; sillimanite + muscovite + quartz; K-feldspar + sillimanite + biotite + muscovite; garnet + muscovite + biotite \pm quartz. Epidote, zircon, apatite and tourmaline are the main accessory phases. Their protolith corresponds to medium- to coarse-grained pelitic sediments, which were affected by a metamorphism reaching the amphibolite facies. They show a porphyroblastic texture with a granolepidoblastic to lepidogranoblastic and poiquiloblastic matrix, which is defined by the alignment of mica minerals and sillimanite developing subparallel bands in a schistose structure. Figures 311 and 312 illustrate the main microstructural and textural features observed in this lithotype.

\section{Andalusite- and cordierite-bearing micaschists}

These rocks are characterized by the presence of andalusite and cordierite porphyroblasts in a matrix mainly composed of muscovite, biotite and quartz, and the typical mineral assemblage is quartz + muscovite + biotite + andalusite; quartz + muscovite + biotite + cordierite; quartz + muscovite + biotite + andalusita + cordierite. The main accessory minerals are tourmaline and epidote. Their protolith corresponds to fine- to medium-grained pelitic sediments, which were affected by a metamorphism reaching the pyroxene-hornfels facies. They show a porphyroblastic texture with granolepidoblastic to lepidogranoblastic and poiquiloblastic matrix. Figures $3 \mathrm{~m} 1$ and $3 \mathrm{~m} 2$ illustrate the main microstructural and textural features observed in this lithotype.

\section{Metagabres}

These highly altered rocks are characterized mainly of muscovite and aggregates of chlorite + epidote, the last of them as a product of alteration of amphibole. The following mineral assembles can be recognized: quartz + muscovite + biotite; garnet + quartz + muscovite. Their protolith 
corresponds to mafic rocks, which were affected by a metamorphism reaching the greenschist facies. They show a porphyroblastic texture with lepidoblastic matrix. Figures 3n1 and 3n2 illustrate the main microstructural and textural features observed in this lithotype.

The backscattered electron (BSE) images in Figure 4 illustrate some examples of the andalusite-cordierite facies metamorphic rocks revealing some interesting relationships between ghost cordierite and relictic andalusite porphyroblasts and matrix. Figures $4 a-4 b$ reveal the occurrence of pelitic schists with pseudomorphs of biotite, muscovite and pinnite after cordierite, with numerous quartz inclusions and ilmenite as the main accessory phases. Note the irregular contact between a ghost cordierite porphyroblast and matrix mineral phases (biotite+muscovite). Figure $4 \mathrm{c}$ shows a typical pelitic schist with a pseudomorph of sericite after andalusite, which is preserved as relics. It is included in a large ghost cordierite porphyroblast similar to those described above. Note the high concentration of biotite in this contact. Ilmenite occurs as the main accessory phase in the matrix, whereas fluorapatite is locally observed as scarce inclusions in the relictic andalusite. Chlorite is commonly observed as a replacement product of biotite in the matrix. Figure 4d illustrates a very fine-grained pelitic schist with numerous biotite and muscovite pseudomorphs. The BSE images in Figures 3S, http://www.raccefyn.co/ index.php/raccefyn/article/downloadSuppFile/108/692 and 4S, http://www.raccefyn.co/index.php/raccefyn/article/ downloadSuppFile/108/..2; show not only the textural relationships between ghost cordierite and relictic andalusite porphyroblasts and matrix but also the semiquantitative energy dispersive spectrum (EDS) analysis at different points.

In Figure 3S, the EDS spectrum of biotite (1) reveals that it mainly consists of $\mathrm{O}, \mathrm{Si}, \mathrm{Al}, \mathrm{Fe}, \mathrm{K}$ and $\mathrm{Mg}$ elements, with minor Ti and $\mathrm{Mn}$. The mass ratios of O:Si:Al:Fe:K:Mg were 29.72:18.49:12.82:17.85:7.44:5.81. The EDS spectrum of muscovite (2) shows that is mainly composed by $\mathrm{O}, \mathrm{Si}, \mathrm{Al}$, $\mathrm{K}, \mathrm{Fe}$ and $\mathrm{Na}$ elements, with mass ratios of $\mathrm{O}: \mathrm{Si}: \mathrm{Al}: \mathrm{K}: \mathrm{Fe}: \mathrm{Na}$ of 34.99:25.40:22.46:8.28:2.10:1.13. The presence of quartz (3) was confirmed in the EDS spectrum, which shows very
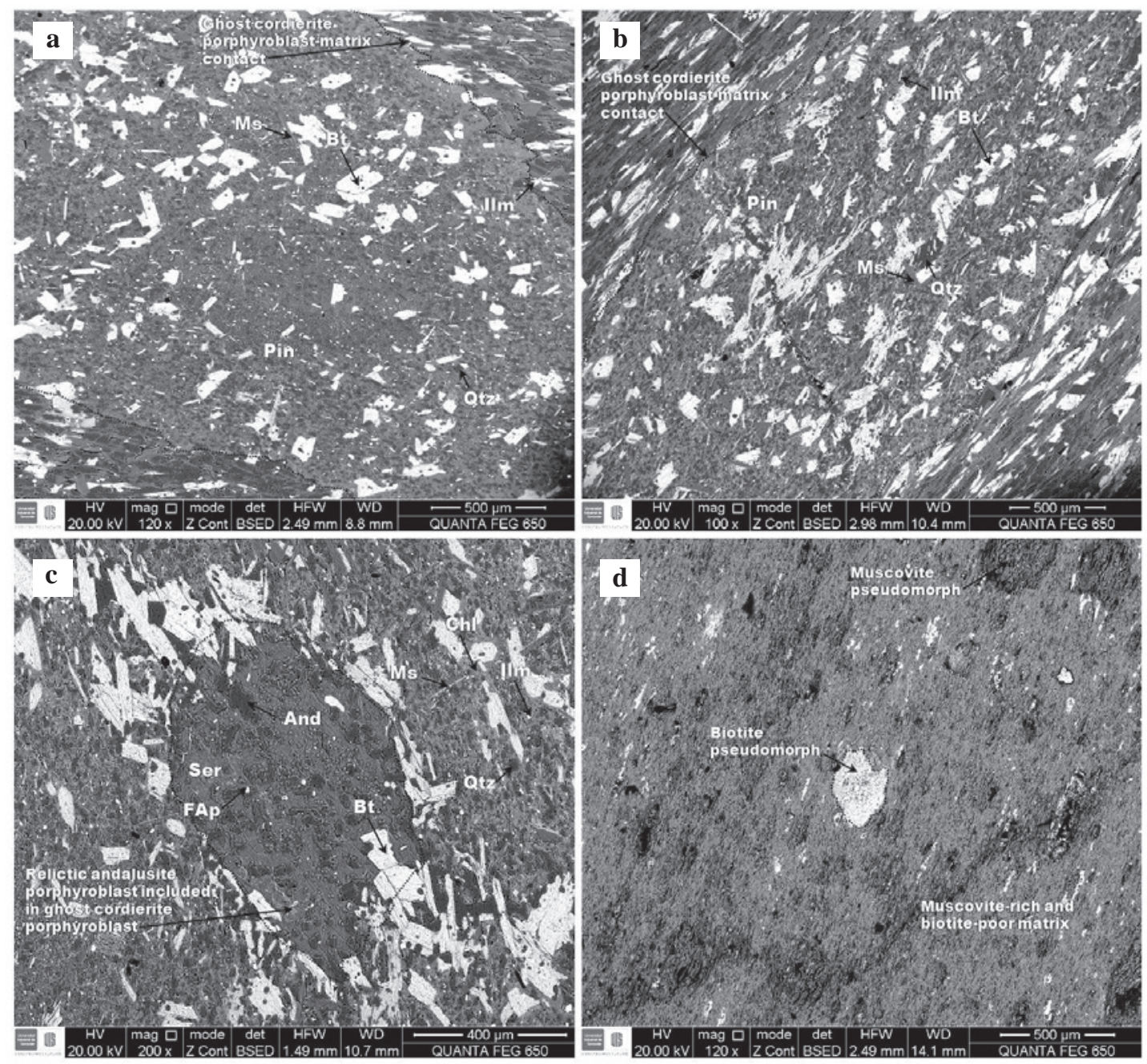

Figure 4. Backscattered electron (BSE) images of pelitic schists from the andalusite-cordierite facies. 
high intensity peaks for $\mathrm{Si}$ and $\mathrm{O}$ (mass ratios of $\mathrm{Si}: \mathrm{O}=$ 41.63:58.37). The EDS spectrum of ilmenite (4) shows that is mainly composed by $\mathrm{O}$, Ti and Fe elements, with mass ratios of O:Ti:Fe of 23.80:32.56:30.75, with minor Mn. The presence of $\mathrm{Si}, \mathrm{Al}$ and $\mathrm{V}$ can be attributed to contamination of the surface of the sample. The EDS spectrum of pinnite (5) shows that is mainly composed by $\mathrm{O}, \mathrm{Si}, \mathrm{Al}, \mathrm{K}, \mathrm{Fe}$ and $\mathrm{Mg}$ elements, with mass ratios of O:Si:Al:K:Fe:Mg of 34. 38:24.27:19.71:7.16:5.32:2.11. EDS spectra are in agreement with literature data (http://www.sfu.ca/ marshall/sem/ mineral.htm).

In Figure 4S, the EDS spectrum of andalusite reveals that it mainly consist of $\mathrm{O}, \mathrm{Si}$ and $\mathrm{Al}$ elements (mass ratios of O:Si:Al of 34.56:45.46:11.01). The EDS spectrum of biotite (2) reveals that it mainly consists of $\mathrm{O}, \mathrm{Si}, \mathrm{Al}$ and K elements, with minor $\mathrm{Na}, \mathrm{Mg}$ and $\mathrm{Fe}$. The mass ratios of $\mathrm{O}: \mathrm{Si}: \mathrm{Al}: \mathrm{K}$ were 33.58:24.92:22.89:8.64. The EDS spectrum of muscovite (3) shows that is mainly composed by $\mathrm{O}, \mathrm{Si}, \mathrm{Al}$, $\mathrm{K}, \mathrm{Fe}$ and $\mathrm{Na}$ elements, with mass ratios of O:Si:Al:K:Fe:Na of 34.99:25.40:22.46:8.28:2.10:1.13. The presence of quartz (4) was confirmed in the EDS spectrum, which shows very high intensity peaks for $\mathrm{Si}$ and $\mathrm{O}$ (mass ratios of $\mathrm{Si}: \mathrm{O}=$ 37.41:54.06). The EDS spectrum of fluorapatite (5) reveals the presence of $\mathrm{Ca}, \mathrm{O}, \mathrm{P}$ and minor $\mathrm{F}$ elements (mass ratios of $\mathrm{Ca}: \mathrm{O}: \mathrm{P}: \mathrm{F}=43.32: 25.45: 20.27: 3.41)$. The EDS spectrum of sericite (6) shows that is mainly composed by $\mathrm{O}, \mathrm{Si}, \mathrm{Al}$ and $\mathrm{K}$ elements, with minor $\mathrm{Fe}$ and $\mathrm{Mg}$, with mass ratios of O:Si:Al:K of 34.01:27.77:18.24:8.11. EDS analysis of chlorite (7) indicates that this alteration mineral show high intensity peaks for $\mathrm{O}, \mathrm{Si}, \mathrm{Al}$ and $\mathrm{Fe}$ and low intensity peaks of $\mathrm{K}$ and $\mathrm{Mg}$ (mass ratios of O:Si:Al:Fe: $\mathrm{K}: \mathrm{Mg}=31.39$ :
20.26:16.23:13.90:6.40:5.44). EDS spectra are in agreement with literature data (http://www.sfu.ca/ marshall/sem/ mineral.htm).

Figure 5 illustrates X-ray elemental maps of $\mathrm{Si}, \mathrm{Al}, \mathrm{Mg}$, $\mathrm{Fe} \mathrm{Na}$ and $\mathrm{K}$ contents from a pelitic schist with a ghost cordierite porphyroblast, which are very useful to discuss the elemental distribution of mineral phases. Note the contrast between Si and $\mathrm{Al}, \mathrm{Mg}$ and Fe contents. There is a strong correlation between $\mathrm{Al}, \mathrm{Mg}$ and $\mathrm{Fe}$ in biotite (in green colors), whereas there is a reverse correlation between $\mathrm{Al}$ (high content - pink color) and Mg and Fe (low content - dark blue to black colors) in sericite and muscovite. The low $\mathrm{Mg}$ and Fe regions in the matrix can be attributed to muscovite. The distribution of $\mathrm{Na}$ and $\mathrm{K}$ shows a reverse behavior and is strongly related to the occurrence of sericite in the pseudomorph after cordierite or muscovite in the matrix. The corresponding maps derived from the X-ray peaks for $\mathrm{Ca}$, Ti and $\mathrm{P}$ (not shown) reveal very low contents.

\section{Metamorphism and structural features}

The mineral paragenesis and textures in the rocks of interest in this study contribute to interpret the relative metamorphism sequence and its associated deformation events. Most rocks in the study area have mineral assemblages from the greenschist facies (especially on the western part), although in the central and eastern parts, mineral assemblages from the amphibolites facies are observed along the contact with Jurassic intrusive bodies and orthogneisses. We suggest a regional metamorphic zonal scheme of Buchan type (andalusite-cordierite) based on our field observations and petrographic analysis, with the following metamorphic
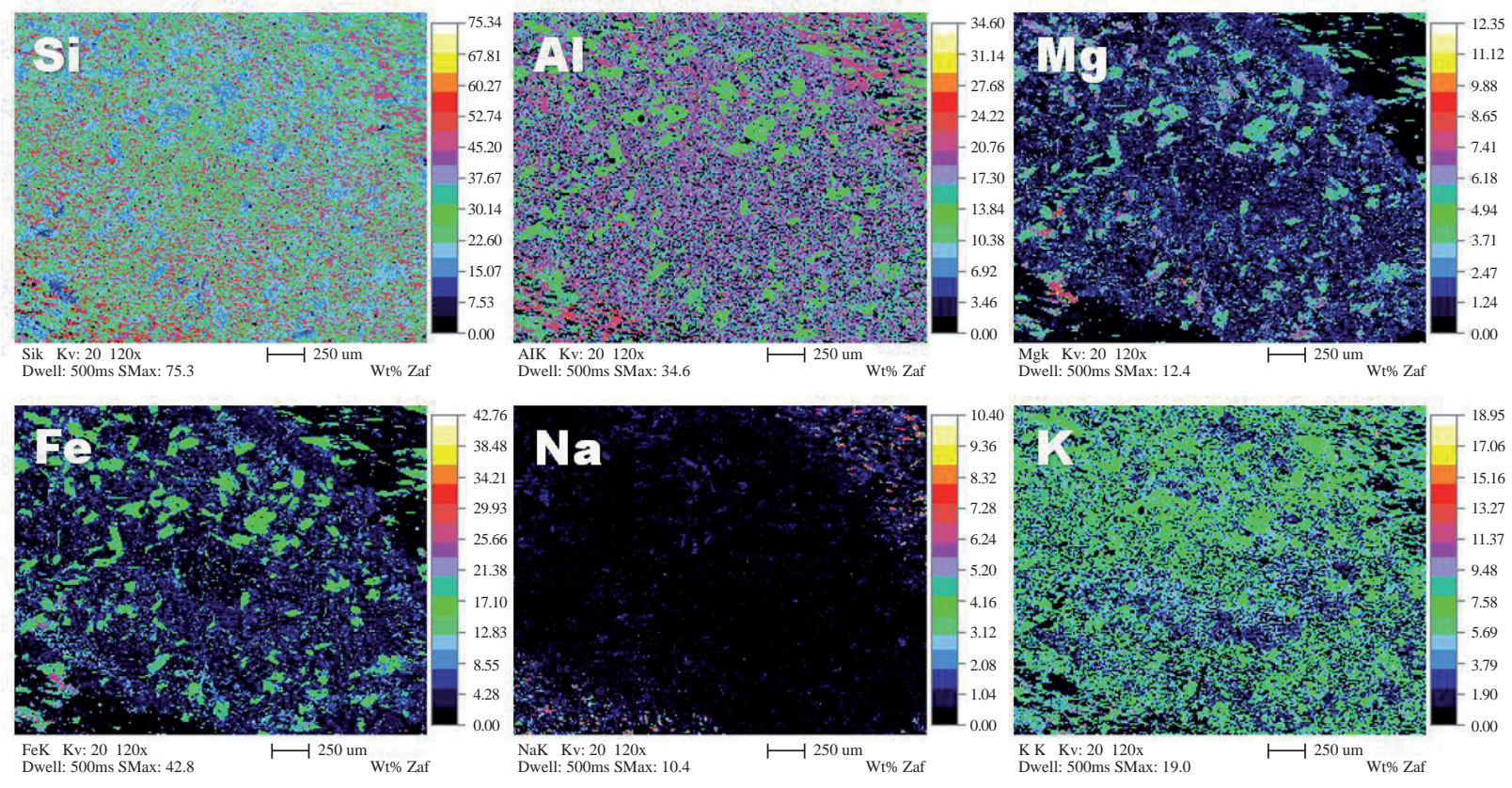

Figure 5. Si, Al, Mg, Fe, Na and K compositional maps of a ghost cordierite porhyroblast (andalusite-cordierite facies). Light colors show areas of high concentration while dark colors represent areas of low concentration (black is very low concentration). 
zones in increasing order of metamorphism: biotite, garnet, andalusite, andalusite-cordierite and sillimanite. The biotite zone is represented by the occurrence of phyllites with thin interbedded slates. Locally, arkose to graywacke metasandstones, metaconglomerates, micaceous schists are observed. These rocks belong to the greenschist facies and the biotite subfacies. The typical mineral assemblage in this metamorphic zone is $\mathrm{Bt}+\mathrm{Ms}+\mathrm{Chl}+\mathrm{Qtz}$. The garnet zone is represented by the occurrence of garnetbearing schists, which belong to the greenschist facies and the garnet subfacies. The typical mineral assemblage in this metamorphic zone is $\mathrm{Bt}+\mathrm{Ms}+\mathrm{Grt}+\mathrm{Pl}+\mathrm{Qtz}$. The andalusite zone is represented by the occurrence of graphite schists with andalusite porphyroblasts, which belong to the amphibolite facies and the andalusite-almandine subfacies. The typical mineral assemblage in this metamorphic zone is And + Grt + Bt + Ms + Qtz. The cordierite-andalusite zone is represented by the occurrence of schists with cordierite, andalusite and garnet porphyroblasts, which belong to the amphibolite facies and the andalusite-almandine subfacies. The typical mineral assemblage in this metamorphic zone is And $+\mathrm{Grt}+\mathrm{Bt}+\mathrm{Ms}+\mathrm{Qtz}$. The sillimanite zone is represented by the occurrence of sillimanite-bearing schists, which belong to the amphibolite facies and the sillimanitealmandine-orthoclase subfacies. The typical mineral assemblage in this metamorphic zone is $\mathrm{Sil}+\mathrm{Grt}+\mathrm{Or}+\mathrm{Pl}+\mathrm{Bt}$ + Qtz. The concepts of metamorphic facies and subfacies were modified after Smulikowski et al. (2007). The mineral assemblages described above indicate their crystallization under high-T and low-P conditions of metamorphism. The Silgará Formation pelitic rocks experienced retrograde metamorphism during the last stage. Retrograde reactions are observed mainly in the higher grade metamorphic zones, including partial replacement of chlorite after garnet rims and fractures, chlorite after biotite, sericite after plagioclase and andalusite and pinnite after cordierite.

A polyphase deformation is revealed by the relationships between the microstructure and mineral assemblages defining it. Several steps of deformation can be recognised in these rocks. The first step of deformation $\left(S_{n}\right)$ is revealed by a dominant foliation (slaty cleavage) defined by chlorite and muscovite in very fine-grained slates and phyllites, chlorite, muscovite and graphite in bimicaceous schists, and biotite and sillimanite in schists. On the othe hand, elongated quartz, and sometimes plagioclase and orthoclase are concordant with the schistosity, which suggests a simultaneous growth during the deformation. The second step of deformation $\left(\mathrm{S}_{\mathrm{n}+1}\right)$ is recognized in all rocks by the folding of the schistosity, developing a crenulation cleavage and/or fracture cleavage developed after $\mathrm{S}_{\mathrm{n}}$. It is important to highlight that quartz, muscovite and biotite occur in the hinges of folds; however, the first of them does not occurs in the flanks of folds, which suggest that during this step of deformation dissolution and recrystallization of quartz happened. A third step of deformation $\left(\mathrm{S}_{\mathrm{n}+2}\right)$ was also observed and is represented by a folding of the flanks in crenulation cleavage $\left(\mathrm{S}_{\mathrm{n}+1}\right)$ and defined by graphite, muscovite, biotite or sillimanite. Later structures, such as kink bands, overprint the main foliation. The Silgará Formation pelitic rocks show evidences that reflect the effect of a shearing process under fragile conditions, which is manifested in the presence of microfaults, shearing, broken crystals and S-C shear bands. These rocks also show shearing zones in ductil conditions, as reflected in the formation of garnet porphyroclasts with development of pressure shadows. In addition, these rocks display other microstructural features, such as wavy extinction in quartz, deformation twinning in plagioclase and dynamic recrystallization processes.

\section{Discussion}

Regional metamorphism of Barrovian type occurs over large areas of the Earth's crust due to crustal thickening in the roots of an orogenic belt. The classic example of a regionally metamorphosed area is the Dalradian series of Scotland, where Barrow (1893) recognized and mapped for the first time a metamorphic field gradient by determining a sequence of metamorphic zones in pelitic rocks based on mineral assemblages as representing increasing grade of metamorphism. The first appearance of an index mineral was taken by Barrow as the beginning of a new metamorphic zone. This mapping was later extended across the Scottish Highlands to cover most of the Dalradian and Moinian Series. The prograde series of Barrovian metamorphic zones is: chlorite - biotite - garnet - staurolite - kyanite - sillimanite. Other authors (e.g., Tilley, 1924, 1925; Kennedy, 1948) confirmed the Barrow zones and extended them across the area between the Highland Boundary Fault and into the Moinian Series. The boundaries connecting the first appearance of a mineral and separating the zones are isograds (Tilley, 1924). Wiseman (1934) mapped the metabasic rocks, whereas Kennedy (1948) and Winchester (1974) mapped the metacalcareous sediments. On the other hand, in northeastern Scotland a regional metamorphism of Buchan type is characterized by the presence of andalusite and sometimes cordierite, in mineral assemblages of intermediate grade pelitic rocks, revealing that the metamorphic conditions were at lower pressure and along a higher metamorphic field gradient than that recorded in a regional metamorphism of Barrovian type. The prograde series of Buchan metamorphic zones is: chlorite - andalusite - sillimanite. Following the concept of index minerals introduced by Barrow to map metamorphic zones, Ríos and co-workers (e.g., Ríos et al., 2003; García et al., 2005; Ríos and Castellanos, 2008) recognized and mapped a medium to high temperature/medium pressure Barrovian sequence of metamorphic zones (biotite, garnet, staurolite and sillimanite) that defines the regional thermal structure of the early Paleozoic Silgará Formation pelitic rocks in the Santander Massif, which range in grade from 
greenschist to upper amphibolites facies conditions. We report for the first time the occurrence of a typical Buchan metamorphic sequence in pelitic rocks of the Silgará Formation at the NSM, which is defined by the presence of chlorite, andalusite and sillimanite zones.

\section{A Buchan metamorphic sequence}

At the NSM, pelitic rocks of the Silgará Formation were affected by a prograde metamorphism, which was followed by a retrograde event after reaching the maximum pressure and temperature conditions. In this study, we recognized a metasedimentary sequence of andalusite-bearing graphite slates, phyllites, garnet-bearing sillimanitic schist, micaschists with or without garnet, andalusite and cordierite-bearing micaschists, quartzites, slightly conglomeratic metasandstones, metawackes and metagabbros. In these rocks the occurrence of andalusite is evident, which indicates that the orogenic metamorphism of Buchan (andalusite-cordierite) type defined in this study occurred at low pressure and high metamorphic field gradient conditions below the $\mathrm{Al}_{2} \mathrm{SiO}_{5}$ triple point as demonstrated by the absence of kyanite and the occurrence of andalusite in pelitic rocks. Pelitic rocks of the Silgará Formation contain low-grade mineral assemblages similar to those of the Barrovian Facies Series previously described in the Santander Massif since the work of Ward et al. (1970, 1973). The greenschist facies rocks show a similar mineralogical composition to that in Barrovian metamorphic sequence, whereas the amphibolite facies rocks, which contain andalusite and cordierite, revealing how the lower-pressure Buchan rocks is distinguished from the higher-pressure Barrovian rocks of the Silgará Formation. The Buchan Facies Series recognized at the NSM may be attributed to a regional metamorphism, which is a result of the emplacement of several intrusions at moderate depths in a continental collision context. According to Miyashiro (1961), a Buchan metamorphism, developing andalusitesillimanite-(cordierite) sequences, has been documented in orogenic belts around the world, such as Scottish Highlands (Caledonian), Pyrenees (Hercynian) and Japan (MesozoicTertiary), among others. These sequences appear to be part of the pattern of orogenic metamorphism and are not related to local causes, such as igneous intrusions (Johnson, 1963). On the other hand, Miyashiro (1961) determined that belts of high-pressure/low-temperature metamorphism on the oceanic side in the Circum-Pacific region were associated with belts of high-pressure/high-temperature metamorphism on the continental side, which were termed as "Paired Metamorphic Belts”. They have been recognized throughout the world, such as the classic paired metamorphic belts of Ryoke and Sambagawa in Japan, as well as other examples in western U.S., New Zealand, Indonesia, Chile, northern coast of South America, Jamaica, Alps of central Europe, among others. We suggest a Caledonian metamorphic belt at the NSM similar to that observed in the classical case in the Scottish Highlands, which Miyashiro described as a lower $\mathrm{P} / \mathrm{T}$ ratio metamorphic belt from an ancient continental margin. Therefore, according to what is reported by Ríos and co-workers (e.g., Ríos et al., 2003; García et al., 2005; Ríos and Castellanos, 2008) and taking into account the results of this study, we consider that the ancient metapelitic sequence of the Santander Massif can be divided into the following regions: a low-P/T region (Buchan type metamorphism) and a medium-P/T region (Barrovian type metamorphism). However, we consider that the low-P/T Buchan type metamorphism has been overimposed on the medium-P/T Barrovian type metamorphism at the NSM. This conclusion is based on petrological evidence obtained in several parts of the Santander Massif, where the authors have investigated the metapelitic rocks, defining mineral assemblages of different metamorphic conditions. Therefore, in this work is suggested to conduct further studies aimed at determining the conditions of metamorphism and P-T paths in order to elucidate different histories of heating, burial, uplift and erosion in the two regions described above.

\section{Metamorphic PT conditions}

We adopt in this study a petrogenetic grid based on previous works on pelitic rocks (e.g., Spear and Cheney, 1989; Spear, 1993), which provides an internally consistent framework and incorporates the effect of Fe-Mg solid solution behavior in all mineral phases. On the other hand, it is in agreement with the sequence of mineral reactions found in pelitic schists of the Silgará Formation as shown in Figure 6. We proposed an anticlockwise PT path, which can be attributed to a crust that was affected by a considerable addition of heat due to magmas (Spear, 1993).

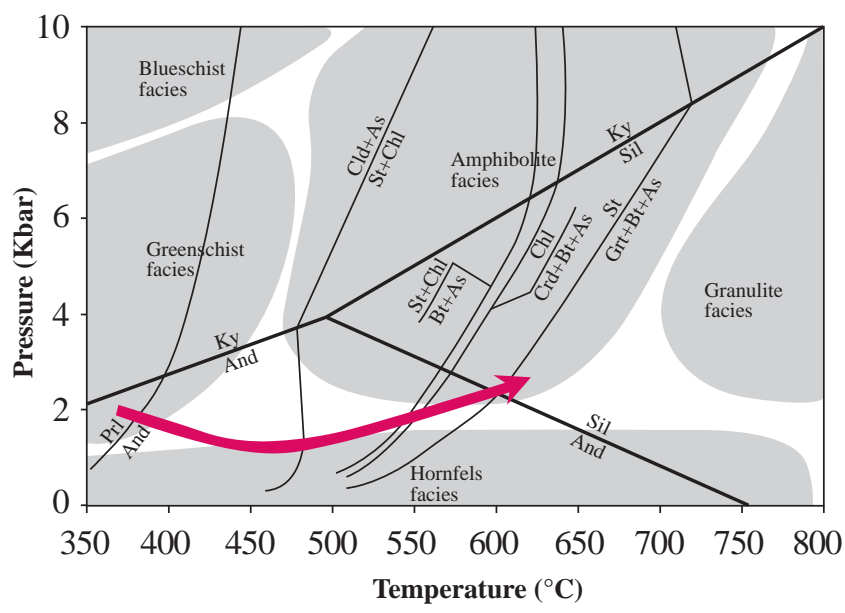

Figure 6. Mineral reactions in the KFMASH system petrogenetic grid (modified after Spear and Cheney (1989), Yardley (1989), and Bucher and Frey (1994)) documented in the metapelitic rocks of the Silgara Formation at the NSM. $\mathrm{Al}_{2} \mathrm{SiO}_{5}$ triple point, after Holdaway (1971). The light gray area represents the metamorphic facies. An anticlockwise PT path (red arrow) followed by the Silgará metapelitic rocks typical of a region that has undergone contact metamorphism. 
The initial conditions along the PT path are in the lowest grade, with a typical mineral assemblage of pyrophyllite +chlorite (all assemblages with quartz + muscovite) in the greenschist facies include below $320^{\circ} \mathrm{C}$. Recently, authors recognized chloritoid in the Silgará Formation pelitic rocks, which occurs at $350{ }^{\circ} \mathrm{C}$ and $2 \mathrm{kbar}$. Therefore, it is probably that the initial conditions can be represented by the mineral assemblage of chloritoid + pryrophyllite + chlorite (all assemblages with quartz + muscovite). Taking into account that the Fe-Mg aluminosilicates are more Fe-rich at low-P than at middle-P, the mineral assemblages will probably loss the major KFMASH isograd producing reactions such as garnet-in and staurolite-in (Spear, 1993), which can explain the absence of garnet and staurolite. At approximately $500{ }^{\circ} \mathrm{C}$ and $1.5 \mathrm{kbar}$, the mineral assemblage can be chlorite+biotite (all assem-blages with quartz+muscovite), although garnet (reported in this study) is present due to sufficient $\mathrm{MnO}$ or $\mathrm{CaO}$ in the chemical system. Following the PT path, at approximately $545^{\circ} \mathrm{C}$ and $1.7 \mathrm{kbar}$, the chemical reaction staurolite+chlorite $=$ andalusite+biotite is crossed, with the production of andalusite in the mineral assemblage andalusite+chlorite+biotite (all assemblages with quartz+muscovite). With an additional increase of the $\mathrm{PT}$ conditions, the reaction chlorite $=$ cordierite + andalusite+biotite is crossed at approximately $550{ }^{\circ} \mathrm{C}$ and $1.8 \mathrm{kbar}$ ), which explain the appearance of cordierite and the terminal stability reaction of chlorite+quartz in the chemical system. Finally, the reaction andalusite $=$ sillimanite occurred at $600{ }^{\circ} \mathrm{C}$ and $2.4 \mathrm{kbar}$, and according to Spear (1993), it is responsible of the final mineral assemblage of sillimanite+biotite+cordierite $(+$ muscovite+quartz+garnet if sufficient $\mathrm{MnO}$ and $\mathrm{CaO}$ are present) in amphibolite facies although, we have not a clear evidence on the occurrence of cordierite.

\section{Conclusions}

The Silgará Formation shows evidence of a regional metamorphism of Buchan type (andalusite-cordierite) attributed to a crust that was affected by a considerable addition of heat due to magmas which was overimposed on the Barrovian metamorphism that characterize this massif. Petrographic analyses of the Silgará Formation metapelitic rocks at the NSM reveal the occurrence of several lithotypes, which include: slates, phyllites, metasandstones, metawackes, micaschists without or with garnet, quartzites, andalusite-bearing slates and schists, garnet-bearing sillimanite schists, andalusite- and cordierite-bearing micaschists and metagabbros. Polyphase deformation is revealed by the relationships between the microstructure and mineral assemblages defining it. Several steps of deformation can be recognized in these rocks. An anticlockwise PT path reveals that the initial conditions are represented by the mineral assemblage of chloritoid+pryrop hyllite+chlorite (all assemblages with quartz+muscovite) in greenschist facies and the final conditions correspond to the mineral assemblage of sillimanite+biotite+cordierite $(+$ muscovite + quartz+garnet if sufficient $\mathrm{MnO}$ and $\mathrm{CaO}$ are present) in amphibolite facies due to the reaction andalusite $=$ sillimanite occurred at $600{ }^{\circ} \mathrm{C}$ and 2.4 kbar.

\section{Información suplementaria}

Figure 1S. Field photographs of the lithostratigraphic features observed in the western (a)-(c), central (c)-(e) and eastern (f) stripes of the Silgará Formation at the NSM.

Figure 2S. Photographs of hand specimens at different scales of the different lithotypes determined in the Silgará Formation metamorphic rocks at the NSM.

Figure 3S. Backscattered electron (BSE) image and EDS spectra at the marked stars on the image of a ghost cordierite porhyroblast (andalusite-cordierite facies). The appearance of $\mathrm{C}$ element is attributed to the carbon coating on the sample before SEM analysis.

Figure 4S. Backscattered electron (BSE) image and EDS spectra at the marked stars on the image of a relictic andalusite porphyroblast (andalusite-cordierite facies). The appearance of $\mathrm{C}$ element is attributed to the carbon coating on the sample before SEM analysis.

\section{Acknowledgments}

This research forms part of the undergraduate thesis of D. Niño. The authors gratefully acknowledge the Universidad Industrial de Santander and the Universidad de Pamplona for supporting research facilities. This study has benefited from these entities and their human resources. Thanks to the Laboratory of Transmitted Light Microscopy of the Research Group in Basic and Applied Geology and the Laboratory of Microscopy of the Guatiguará Technological Park and its professional staff for assistance with SEM data acquisition. Authors also thank members of the Research Group in Basic and Applied Geology for their helpful discussions and constructive comments. We express thanks to anonymous reviewers for helpful comments and suggestions of this manuscript. We are most grateful to the above-named people and institutions for support.

\section{Conflict of interests}

The authors declare no conflicts of interest of any kind.

\section{Bibliography}

Banks P., Vargas R., Rodríguez G.I. \& Shagam, R. (1985). Zircon U-Pb ages from orthogneiss, Pamplona, Colombia. VI Congreso Latinoamericano de Geología. Bogotá. Resúmenes. 
Barrow G. (1893). On an intrusion of muscovite-biotite-gneiss in the south-eastern Highlands of Scotland, and its accompanying metamorphism. Quarterly Journal of the Geological Society of London. 49: 330-358.

Barrow G. (1912). On the geology of Lower Dee-side and the southern Highland border. Proceedings of the Geologists' Association. 23: 272-290.

Boinet T., Bourgois J., Bellon H. \& Toussaint, J. (1985). Age et repartition du magmatism premesozoique des Andes de Colombie. Comptes rendus hebdomadaires des séaces de L'Académie des Sciences. Serie D: Sciences Naturalles. 300 (II): 445-450.

Bucher K. \& Frey M. (1994). Petrogenesis of Metamorphic Rocks. $6^{\text {th }}$ edition Complete revision of Winkler's textbook. Springer-Verlag, Berlin Heidelberg, Germany, 318p.

Campos N. (1999). Estudio Mineralógico y Petrográfico de las Metamorfitas al Occidente del Municipio de Mutiscua (Norte de Santander). Tesis de Pregrado, Universidad Industrial de Santander, Bucaramanga (Colombia).

Cardona A. (2003). Correlacoes entre fragmentos do embasamento Pre-Mesozoico da terminacao setentrional dos Andes Colombianos, com base em datos isotopicos e geocronologicos. Dissertacao de Mestrado, Universidade de Sao Paulo, Instituto de Geociencias, 149pp.

Castellanos O.M. (2001). Chemical composition of the rockforming minerals in the Silgará formation and P-T conditions in the Mutiscua area, Santander Massif, Eastern Cordillera, Colombia. Unpublished Master Thesis, Shimane University, Matsue (Japan), 146 pp.

Castellanos, O.M., Ríos, C.A. \& Takasu A. (2004). Chemically sector-zoned garnets in the metapelitic rocks of the Silgará Formation in the central Santander Massif, Colombian Andes: occurrence and growth history, Boletín de Geología. 26: 91-98.

Castellanos, O.M., Ríos, C.A. \& Takasu A. (2008). A new approach on the tectonometamorphic mechanisms associated with $\mathrm{P}-\mathrm{T}$ paths of the Barrovian-type Silgará Formation at the Central Santander Massif, Colombian Andes. Earth Sciences Research Journal. 12: 125-155.

Castellanos, O.M., Ríos, C.A. \& Takasu A. (2010). X-ray color maps of the zoned garnets from Silgará Formation metamorphic rocks, Santander Massif, Eastern Cordillera (Colombia). Earth Sciences Research Journal. 14: 161-172.

Clavijo J. (1997). Mapa Geológico Generalizado del Departamento de Norte de Santander, Escala 1:250000. Ingeominas.

Dörr W., Grösser J., Rodriguez G. \& Kramm U. (1995). Zircon U-Pb age of the Páramo Rico tonalite-granodiorite, Santander Massif (Cordillera Oriental, Colombia) and its geotectonic significance. Journal of South American Earth Sciences. 8 (2): 187-194.

García C.A \& Campos N. (2000). Composición química y mineralogía de las biotitas metamórficas del sector central del Macizo de Santander, Colombia. Boletín de Geología 22 (37): 18-27.

García C.A., Ríos C.A. \& Castellanos O.M. (2005). Mediumpressure metamorphism in the central Santander Massif,
Eastern Cordillera, Colombian Andes: constraints for a collision model. Boletín de Geología. 27: 43-68.

Gélvez J. \& Márquez R. (2002). Caracterización textural del granate y de sus elementos de deformación asociados, y modelamiento de su historia de nucleación y crecimiento en las rocas metapelíticas de la Formación Silgará en la región suroccidental del Macizo de Santander. Tesis de Pregrado, Universidad Industrial de Santander, Bucaramanga (Colombia).

Goldsmith R., Marvin R. \& Mehnert, H. (1971). Radiometric ages in the Santander Massif, eastern Cordillera, Colombian Andes. U.S. Geological Survey Professional Paper. 750-D (D41-D49).

Gómez S.I. \& Avila G.A. (2006). Petrogénesis de las rocas calcosilicatadas que ocurren como bandas de reacción entre mármoles y rocas metapelíticas de la Formación Silgará, región Central del Macizo de Santander. Tesis de Pregrado, Universidad Industrial de Santander, Bucaramanga (Colombia).

Kennedy W.Q. (1948). Zones of Progressive Regional Metamorphism in the Moine Schists of the Western Highlands of Scotland. Geological Magazine. 86 (1): 43-56.

Kretz R. (1983). Symbols for rock-forming minerals. American Mineralogist. 68: 277-279.

Holdaway M. (1971). Stability of andalusite and the aluminum silicate phase diagrams. American Journal of Sciences. 271: 97-131.

Johnson M.R.W. (1963). Some time relations of movement and metamorphism in the Scottish Highlands. Netherlands Journal of Geosciences / Geologie en Mijnbouw. 42: 121142.

Mantilla L.C., Ordoñez J., Cepeda S. \& Ríos, C.A. (2001). Study of the paleofluids in the Silgará Formation and their relationship with deformation processes, AratocaPescadero area (southwestern Santander Massif). Boletín de Geología. 23 (38): 69-75.

Mantilla L.C., Ríos, C.A. \& Castellanos, O. (2002). Study of the rehydratation process of the Silgará Formation metamorphic rocks, from the compositional analysis of chlorite, southwestern Santander Massif. Boletín de Geología. 24 (39): 7-17.

Mantilla L.C., Ríos C.A., Gélvez J., Márquez R., Ordoñez J. \& Cepeda, S. (2003). New evidences on the presence of a shear band in the metapelitic sequence of the Silgará Formation, Aratoca-Pescadero area (southwestern Santander Massif). Boletín de Geología. 25 (40): 81-89.

Mantilla L.C., Bissig, T., Cottle, J.M. \& Hart, C. (2012). Remains of early Ordovician mantle-derived magmatism in the Santander Massif (Colombian Eastern Cordillera). Journal of South American Earth Sciences. 38: 1-12.

Mantilla, L.C., García, C.A. \& Valencia, V. (2015). Propuesta de escisión de la denominada "Formación Silgará” (Macizo de Santander, Colombia) a partir de edades U-Pb en circones detríticos. Boletín de Geología (En edición).

Miyashiro, A. (1961). Evolution of metamorphic belts. Journal of Petrology. 2: 277-311. 
Montenegro G. \& Barragán M. (1999). Metamorfismo y evolución metamórfica del área comprendida entre los municipios de Vetas (Santander) y Mutiscua (Norte de Santander). Tesis de Pregrado, Universidad Industrial de Santander, Bucaramanga (Colombia).

Ordoñez J.C. (2003). Petrology and geochemistry of the granitoids at the Santander Massif, Eastern Cordillera, Colombian Andes. Unpublished Master Tesis, Shimane University, Matsue (Japan), 150pp.

Ordóñez J.C. \& Mantilla, L.C. (2004). Significance of an early Cretaceous Rb-Sr age in the Pescadero Pluton, Santander Massif. Boletín de Geología. 26 (43): 115-126.

Restrepo-Pace P. (1995). Late Precambrian to Early Mesozoic tectonic evolution of the Colombian Andes, based on new geochronological, geochemical and isotopic data. Unpublished PhD Thesis, University of Arizona, 195pp.

Restrepo-Pace P., Ruiz J., Gehrels G. \& Cosca, M. (1997). Geochronology and $\mathrm{Nd}$ isotopic data of Grenville-age rocks in the Colombian Andes: New constraints for late Proterozoic-early Paleozoic Paleocontinental reconstruction of the Americas. Earth and Planetary Sciences Letters. 150: 427-441.

Ríos C.A. (1999). Chemical compositions of the constituent minerals and P-T conditions of the low-grade Silgará Formation metamorphic rocks in the Santander Massif, Eastern Cordillera, Colombian Andes. Master Thesis. Shimane University, Matsue (Japan), 207pp.

Ríos C.A. \& Takasu, A. (1999). Chemical zoning of garnet from the low-grade metamorphic rocks of the Silgará Formation, Santander Massif, Eastern Cordillera (Colombian Andes). Geosciences Reports of Shimane University. 18: 97-107.

Ríos C.A. (2001). Occurrence, chemical composition and genetic significance of the biotite in the Silgará Formation metamorphic rocks, southwestern Santander Massif, Eastern Cordillera, Colombian Andes. Boletín de Geología. 23 (38): 41-49.

Ríos C.A. \& García C.A. (2001). First occurrence of the three $\mathrm{Al}_{2} \mathrm{SiO}_{5}$ polymorphs in the Silgará Formation metapelitic rocks, southwestern Santander Massif, Eastern Cordillera, Colombian Andes. Boletín de Geología. 23 (38): 51-59.

Ríos C.A., García C.A. \& Takasu, A. (2003a). Tectonometamorphic evolution of the Silgará Formation metamorphic rocks in the southwestern Santander Massif, Colombian Andes. Journal of South American Earth Sciences. 16: 133-154.

Ríos C.A., Gelvez J. \& Marquez R. (2003b). Kynetics of the nucleation and growth garnet in the Silgará Formation metapelitic rocks, southwestern Santander Massif, Boletín de Geología. 25: 23-38.

Ríos C.A. (2005). Cation substitutions governing the chemistry of amphibole in the Silgará Formation metabasites at the southwestern Santander Massif. Boletín de Geología. 27 (2): 13-30.

Ríos C.A., Castellanos O.M. \& Takasu A. (2008a). A new interpretation for the garnet zoning in metapelitic rocks of the Silgará Formation, southwestern Santander Massif, Colombia. Earth Sciences Research Journal. 12: 7-30.

Ríos C.A., Castellanos O.M., Gómez S.I \& Avila G. (2008b). Petrogenesis of the metacarbonate and related rocks of the Silgará Formation, central Santander Massif, Colombian Andes: An overview of a "reaction calcic exoscarn". Earth Sciences Research Journal. 12: 72-106.

Schäfer J., Grösser J. \& Rodríguez G. (1998). Proterozoic Formación Silgará, Cordillera Oriental, Colombia: metamorphism and geochemistry of amphibolites. Zentralblatt für Geologie und Paläontologie (Teil I) (3-6) (531-546).

Smulikowski W., Desmons J., Fettes D., Harte B, Sassi F.P. \& Schmid R. (2007). A systematic nomenclature for metamorphic rocks: 2. Types, grade and facies of metamorphism. Recommendations by the IUGS Subcommission on the systematics of metamorphic rocks. SCMR website (HUwww.bgs.ac.uk/SCMRUH).

Spear F. (1988). Thermodynamic projection and extrapolation of high variance mineral assemblages. Contributions to Mineralogy and Petrology. 98: 346-351.

Spear, F. (1993). Metamorphic phase equilibria and pressuretemperature-time paths, Monograph Series, Mineralogical Society of America, Washington, DC, 799pp.

Spear F. \& Cheney J. (1989). A petrogenetic grid for pelitic schists in the system $\mathrm{SiO}_{2}-\mathrm{Al}_{2} \mathrm{O}_{3}-\mathrm{FeO}-\mathrm{MgO}-\mathrm{K}_{2} \mathrm{O}-$ $\mathrm{H}_{2} \mathrm{O}$. Contributions to Mineralogy and Petrology. 101: 149-164.

Tilley C.E. (1924). Contact-Metamorphism in the Comrie Area of the Perthshire Highlands. Quarterly Journal of the Geological Society of London. 80: 22-71.

Tilley C.E. (1925). A Preliminary Survey of Metamorphic Zones in the Southern Highlands of Scotland. Quarterly Journal of the Geological Society of London. 81: 100-112.

Ward D.E., Goldsmith R., Jimeno V., Cruz B.J., Restrepo H. \& Gómez, R. (1969). Mapa Geológico del Cuadrángulo $\mathrm{H}-12$, Bucaramanga, Colombia. Ingeominas.

Ward D.E., Goldsmith R., Cruz B.J., Jaramillo, C.L. \& Vargas, L.R. (1970). Mapa Geológico del Cuadrángulo H-13, Pamplona, Colombia. Ingeominas.

Ward D.E., Goldsmith R., Cruz B.J., Jaramillo C.L. \& Restrepo, H. (1973). Geología de los Cuadrángulos H-12, Bucaramanga y H-13, Pamplona, Departamento de Santander. U.S. Geological Survey e Ingeominas. Boletín Geológico XXI(1-3), 1-132.

Wiseman J.D.H. (1934). The Central and South-West Highland Beidiorites: A.Study in progressive Metamorphism, Quarterly Journal of the Geological Society of London. 90: 354-417.

Winchester J.A. (1974). The zonal pattern of regional metamorphism in the Scottish Caledonides. Journal of the Geological Society of London. 130 (6): 509-524.

Yardley B. (1989). An Introduction to Metamorphic Petrology, Longman, Harlow, England, 248pp. http://www.sfu. ca/ marshall/sem/mineral.htm Mineral Energy Dispersive Spectra (EDS) Consulted on 25 March, 2014. 